\title{
The incidence of acute kidney injury in patients with traumatic brain injury
}

\author{
R Avila*, N Carrizo, A Fernandez, MM Filippi \\ From ESICM LIVES 2015 \\ Berlin, Germany. 3-7 October 2015
}

\section{Intr}

There are a few researches that investigated non-neurological complications in traumatic brain injury (TBI) and reported a low incidence of acute kidney injury(AKI). Probably most of them did not use the scores validated for AKI, likely only identify patients with severe AKI.

\section{Objectives}

The aim of this study was to determine the incidence of AKI using a reliable score as classified by the RIFLE criteria.

\section{Methods}

We study all patients, 16 years and over, with moderate or severeTBI (Glasgow score $<13$ ) and admitted to the intensive care unit (ICU) in a Trauma Intensive Care Unit Level III (Hospital Cullen) in Santa Fe, Argentina from 1 January 2014 to 31 December 2014.

Prospectively collected data of AKI from the ICU trauma registry and pathology database was analyzed retrospectively(Hardinero Quality). Risk injury failure loss end (RIFLE) criteria were used to categorize renal function.

\section{Results}

The incidence of AKI was 17 \% (29/169). RIFLE (F10,I5, R13) Patients who developed AKI were older, had higher severity of illness scores, and a lower GCS. ICU mortality : AKI group 58\% compared with $30 \%$ in patients without AKI.

\section{Conclusions}

In patients with TBI the incidente of AKI is relatively common and identifies patients with a high risk of death. Age, APACHE II and lower Glasgow score identify patients with high risk of AKI.

Hospital Cullen, Santa Fe, Argentina
Published: 1 October 2015

\section{References}

1. Moore Elizabeth M, Bellomo Rinaldo, Nichol Alistair, Harley Nerina:

2. Maclsaac Christopher, Cooper D. James: The incidence of acute kidney injury in patients with traumatic brain injury. Renal Failure 2010, 32(9):1060-1065.

3. Zygun D, Kortbeek J, Fick G, Laupland KB, Doig CJ: Nonneurologic organ dysfunction in severe traumatic brain injury. Crit Care Med 2005, 33:654-660.

doi:10.1186/2197-425X-3-S1-A263

Cite this article as: Avila et al:: The incidence of acute kidney injury in patients with traumatic brain injury. Intensive Care Medicine Experimental 2015 3(Suppl 1):A263.
Submit your manuscript to a SpringerOpen ${ }^{\circ}$ journal and benefit from:

- Convenient online submission

- Rigorous peer review

- Immediate publication on acceptance

- Open access: articles freely available online

- High visibility within the field

Retaining the copyright to your article

Submit your next manuscript at $>$ springeropen.com

\section{SpringerOpen ${ }^{\circ}$}

(C) 2015 Avila et al.; This is an Open Access article distributed under the terms of the Creative Commons Attribution License (http:// creativecommons.org/licenses/by/4.0), which permits unrestricted use, distribution, and reproduction in any medium, provided the original work is properly cited. 